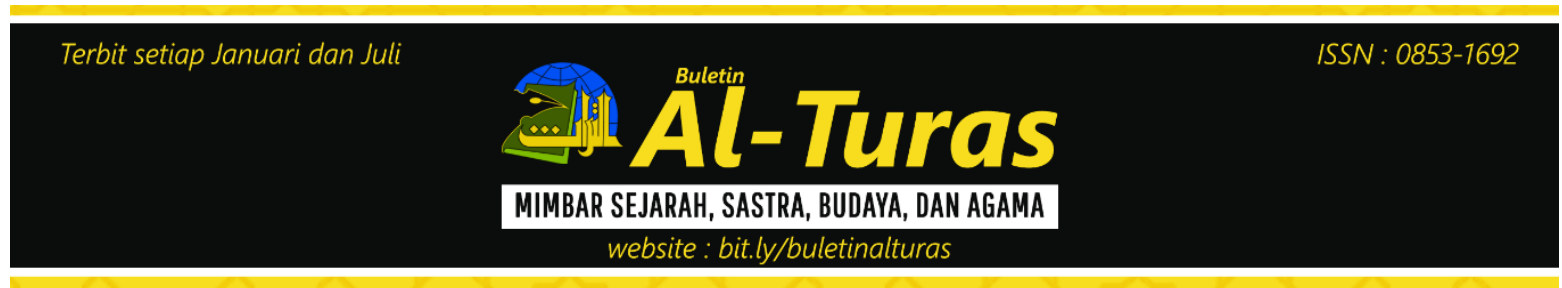

\title{
Sejarah dan Peranan Masjid Gammalamo Jailolo Halmahera dalam Menyingkap Jejak Warisan Budaya Kesultanan Jailolo
}

\author{
Novita Siswayanti ${ }^{1}$
}

\begin{abstract}
Gammalamo Mosque is the oldest and the first mosque that have stood in Jailolo Halmahera. Gammalamo mosque as one of the historic buildings that symbolize the inherited social and cultural traces Jailolo Sultanate in the spread of Islam and broadcasting incorporated in Maloko Kie Raha four sultanates of Ternate in North Maluku, Tidore, Jailolo, and Bacan. Research on Gammalamo Mosque is done with historical and archaeological approach in tracing the history of the mosque, revealing the unique architecture of its buildings and the symbolism contained in them and reveal the cultural heritage of the Sultanate Jailolo which is still preserved in the role of Islam broadcast
\end{abstract}

Keyword: Gammalamo Mosque, cultural heritage, Sultanate Jalolo

\section{Abstrak}

Masjid Gammalamo adalah Masjid pertama dan tertian yang telah berdiri di Jailolo Halmahera. Masjid Gammalamo sebagai salah satu gedung-gedung bersejarah yang melambangkan jejak sosial dan budaya warisan Jailolo Kesultanan dalam penyebaran Islam dan penyiaran yang tergabung dalam Maloko Kie Raha empat Kesultanan Ternate di Maluku Utara, Tidore, Jailolo, dan ditandai. Penelitian pada Masjid Gammalamo dilakukan dengan pendekatan historis dan arkeologis dalam menelusuri sejarah masjid, mengungkapkan arsitektur yang unik dari bangunan dan simbolisme yang terkandung di dalamnya dan mengungkapkan warisan budaya Jailolo Kesultanan yang masih disimpan dalam peran Islam siaran.

Kata Kunci: Masjid Gammalamo, warisan budaya, Kesultanan Jalolo

\footnotetext{
${ }^{1}$ Puslitbang Lektur dan Khazanah Keagamaan, KEMENAG
} 


\section{A. Pendahuluan}

Masjid sebagai bangunan rumah ibadah merupakan salah satu simbol keberadaan Islam pada suatu masyarakat atau komunitas. Keberadaannya tidak dapat dipisahkan dari aktivitas ritual keagamaan sebagai wujud ketaatan seorang hamba kepada Sang Pencipta dan media dalam melakukan hubungan sosial budaya sesama manusia. ${ }^{2}$ Selain itu masjid juga merupakan salah satu karya budaya masyarakat Islam di bidang teknologi konstruksi arsitektur yang tumbuh dan berkembang atas ruang dan waktu. Masjid di mana saja berada menjadi representasi perkembangan arsitektur kesenian Islam yang diwakili oleh bangunannya. ${ }^{3}$

Masjid Gammalamo sebagai bangunan rumah ibadah pertama dan tertua yang berdiri kokoh di Kota Jailolo Halmahera Barat merupakan representasi eksistensi dakwah dan syiar Islam yang sudah bermetamorfosis secara fisik maupun tradisi budaya sejak masa berdirinya hingga masa sekarang. Masjid Gammalamo sebagai saksi sejarah yang menorehkan beragam kisah dan cerita yang menyingkapkan jejak-jejak warisan budaya Kesultanan Jailolo yang tergabung dalam Moloku Kie Raha. Masjid Gammalamo walaupun secara fisik bangunannya telah mengalami tiga kali renovasi, namun secara filosofis arsitektur bangunannya tetap dipertahan kan keasliannya.

Bangunan Masjid Gammalamo secara umum sebenarnya tidak ada yang istimewa, namun tetap memiliki daya pikat tersendiri. Masjid Gammalamo baik dari segi arsitektur bangunannya maupun peran dan fungsinya mengungkapkan dinamika perjalanan sejarah budaya Islam Kesultanan Jailolo yang tergabung dalam persatuan empat kerajaan Moloku Kie Raha di Maluku Utara. Kesultanan Jailolo juga

2 Hasan Muarif Ambary, Menemukan Peranan Jejak Arkeologi dan Historis Islam di Indonesia, (Jakarta: Logos Wacana Ilmu, 1998), h. 68.

3 Abdul Rochym. Masjid dalam Karya Arsitektur Nasional Indonesia. (Bandung: Angkasa, 1983), h. 1. merupakan salah satu penghasil cengkeh terbesar yang disebut sebagai the spice of island. ${ }^{4}$

Lokasi Masjid Gammalamo berada di pesisir pantai Teluk Jailolo merefleksikan eksistensi komunitas muslim di Jailolo Halmahera. Halmahera pulau besar penduduk nya heterogen dari berbagai suku dan agama. Penyebaran Islam di Halmahera didominasi oleh masyarakat pesisir, sedangkan masyarakat pedalaman menganut agama Kristen yang disebarkan oleh zending Kolonial Belanda. Tiap suku dan penganut agama di Jailolo memiliki perkampungan khusus muslim dan Kristiani. Namun demikian walaupun penduduk Jailolo heterogen, mereka tetap bersatu dan saling tolong menolong satu sama lain. Masjid Gammalamo sebagai representasi persatuan dan kesatuan seluruh suku dan agama yang ada di Jailolo karena soko guru (di Jailolo disebut tiang ka'ba) pada Masjid Gammalamo merupakan pemberian dan simbolisasi suku-suku yang ada di Jailolo. ${ }^{5}$

Dalam perkembangan selanjutnya, dari masa ke masa Masjid Gammalamo memainkan peran dan fungsi yang amat penting dalam dakwah dan syiar Islam di Jailolo. Selain itu strukturisasi kelembagaan Masjid Gammalamo merekonstruksi masa Kesultanan Jailolo dengan tetap melestarikan dan menerapkan falsafah dan adat seatorang Moloku Kie Raha yang bersendikan pada nilai-nilai ajaran Islam. "Adat ma toto agama, Agama ma toto toma Jou Rasulullah, Jou Rasulullah manyeku Diki Amoi nga hidayah se kodrati'. (Adat bersumber dari agama, agama bersumber dari ajaran Rasullulah, dia atas Rasulullah hanya hidayah dan kehendak- Nya atas segalanya". ${ }^{6}$

Untuk menyingkap jejak warisan budaya Kesultanan Jailolo yang

\footnotetext{
Irza Arnyta Djafaar. Jejak Portugis di Maluku Utara, (Maluku Utara: Ombak, 2007), h. 25.

5 Wawancara: Awwad Lolory, Jogogo Kesultanan Jailolo (22-29 April 2014).

${ }^{6}$ Abdul Hamid Hasan, Aroma Sejarah dan Budaya Ternate, Ternate: t.p., 1999), h. 26.
} 
tersimbolisasikan pada Masjid Gammalamo, maka penelitian terhadap Masjid Gammalamo menarik untuk dikaji; bukan hanya menggali nilai-nilai tradisi dan peninggalan sejarah Islam di Indonesia, tetapi juga bukti-bukti historis masjid ini masih sangat jelas terlihat. Sebab, masjid ini selain sebagai saksi sejarah yang paling nyata, masjid ini sebagai salah satu bukti peninggalan arkeologi masa Islam dan simbol keberadaan Islam di Jailolo..

Sehubungan dengan hal tersebut, rumusan masalah dalam penelitian Masjid Gammalamo Jailolo Halmahera adalah:

1. Bagaimana konteks latar sejarah Masjid Gammalamo? Pertanyaan ini meliputi; kapan berdirinya, siapa tokoh pendirinya, dan kondisi masyarakat di sekitar saat berdirinya?

2. Bagaimana model arsitektur bangunan Masjid Gammalamo serta pemaknaan yang terkandung pada benda yang ada?

3. Bagaimana peran Masjid Gammalamo sebagai pelestarian warisan budaya Kesultanan Jailolo dalam penyebaran agama sejak awal berdiri hingga saat ini?

Tujuan dan Kegunaan Penelitian: Berdasarkan pokok permasalahan Penelitian Sejarah Masjid Gammalamo sebagaimana tersebut di atas, maka penelitian bertujuan:

1. Untuk mengungkapkan konteks latar sejarah berdirinya Masjid Gammalamo, yang meliputi waktu, pendiri, serta kondisi masyarakat di sekitar saat itu.

2. Didapatnya data tentang model arsitektur bangunan Masjid Gammalamo dan benda-benda berikut makna filosofis yang terkandung di dalamnya

3. Mengetahui peran Masjid Gammalamo sebagai pelestarian warisan budaya Kesultanan Jailolo dalam penyebaran agama sejak awal berdiri hingga saat ini

Dari tujuan tersebut penelitian ini diharapkan dapat mendeskripsikan historis, model arsitektur dan peran sosial budaya keberadaan Masjid Gammalamo sehingga dapat menambah khazanah keagamaan Nusantara, menggali nilai-nilai kearifan lokal dan mengkonservasi dan melestarikan tempat-tempat ibadah keagamaan bersejarah di Indonesia.

Metodologi Penelitian Rumah Ibadah Besejarah Masjid Gammalamo Jailolo menggunakan pendekatan historis dan arkeologis. Pendekatan historis dilakukan untuk mendeskripsikan latar belakang sejarah keberadaan Masjid Gammalamo. Sedangkan pendekatan arkeologis dilakukan untuk mendeskripsikan struktur fisik bangunan Masjid Gammalamo dan makna yang terkandung di dalamnya, dengan tujuan untuk mengungkap kehidupan manusia masa lalu melalui kajian atas tinggalantinggalan kebendaanya. ${ }^{7}$ Berdasarkan kedua pendekatan tersebut, metode pengumpulan data yang digunakan dalam penelitian ini adalah: interview, observasi, dan kajian pustaka meliputi kajian artefak, etnografi, historis. Sedangkan sumber data primer diperoleh langsung dari responden dan informan, yaitu Jogugu Kesultanan Jailolo, Pemuka adat dan sejarawan, Imam dan Pengurus Masjid, dan Dinas Pariwisata dan Kebudayaan. Sementara data sekunder diperoleh dari Perpustakaan, Badan Pelestarian Budaya, Badan Pusat Statistik dan Pusat Informasi Lainnya.

Kajian Pustaka: Kajian dan penelitian Masjid Gammalamo Jailolo belum pernah dilakukan sebelumnya. Namun demikian Jailolo merupakan salah satu Kesultanan yang tergabung dalam Moloku Kie Raha (Ternate, Bacan, Jailolo, dan Tidore) dan memiliki hubungan yang erat dalam kekerabatan, sosial, budaya dan politik dengan Kesultanan Ternate. Oleh karena itu dalam mengungkapkan arsitektur dan sejarah sosial Masjid Gammalamo Jailolo referensi yang digunakan adalah: Sejarah Sosial Kesultanan Ternate (Tim Peneliti IAIN

\footnotetext{
7 Ali. Akbar. Arkeologi Masa Kini, (Bandung: ALQAPRINT, 2010), h. 7.
} 
Ternate: 2010) yang berisikan dinamika perkembangan sosial dan budaya Masyarakat Ternate sejak masa monopoli perdagangan rempah-rempah sampai peranannya dalam penyiaran dan penyebaran Islam di Maluku Utara; Selain itu buku berjudul Maluku Utara Perjalanan Sejarah 1250-1800 (Amal: 2002) yang mengungkapkan sejarah singkat perjalanan Kesultanan Moloku Kie Raha dari berbagai aspek kehidupannya serta penyebaran agama-agama di Maluku Utara dan referensi yang terpenting adalah Sejarah Masjid-Masjid Kuno di Indonesia ${ }^{8}$ yang menelusuri jejak arkeologi arsitektur bangunan; sejak awal berdirinya sampai renovasi; serta fungsi dan peranan masjidmasjid kuno di Indonesia.

\section{B. Pembahasan}

\section{Sejarah Berdirinya Masjid Gammalamo}

Masjid Gammalamo berada di komunitas muslim Halmahera Barat. Masyarakat muslim Halmahera Barat pada umumnya berdiam di teluk-teluk dan pesisir pantai, karena wilayah pedalaman masih belum tersentuh Islam. Masjid Gammalamo terletak di pesisir pantai Pelabuhan Gufasa yang berseberangan langsung dengan Pelabuhan Dufa-Dufa Ternate. Masjid ini berada di lokasi yang strategis mudah dijangkau dari berbagai desa; Sebelah Barat berbatasan dengan Desa Jalan Baru; Sebelah Utara berbatasan dengan Desa Sokonora, Sebelah Selatan berbatasan dengan Desa Gufasa dan Sebelah Timur berbatasan dengan Hutan Mangrove tepat di Teluk Jailolo. ${ }^{9}$

Masjid Gammalamo masjid tertua yang dibangun pada awal tahun 1900-an atas swadaya masyarakat yang bergotongroyong bahu-membahu mendirikan tempat ibadah. Berawal tidak adanya bangunan rumah ibadah bagi kaum muslim di

\footnotetext{
8 Departemen Agama, Badan Litbang Agama, Sejarah Masjid-Masjid Kuno di Indonesia, (Jakarta: Badan Litbang Agama Departemen Agama, 1999)

${ }^{9}$ Wawancara: M. Samad, (22-29 April 2014).
}

Jailolo, maka atas prakarsa Suku Moro (suku tertua di Jailolo) rakyat Jailolo bersepakat dan berswadaya mendirikan masjid. Empat suku di Jailolo yaitu suku Moro, Wayuli, Porniti, Gammalamo baik itu yang beragama Islam maupun Kristen turut berpartisipasi membangun Masjid Gammalamo. Tiap-tiap suku memberikan kontribusi berupa pemasangan tiang kaba (soko guru) pada ruang ibadah masjid. tiang Kaba sebagai simbolisasi persatuan dan kesatuan rakyat Jailolo yang saling bersaudara dan tetap menjaga hubungan baik antarsesama walau beda suku dan agama. ${ }^{10}$

Setelahnya masjid ini berdiri dan difungsikan sebagai rumah ibadah dan tempat bermusyawarah seluruh suku di Gammalamo, pada tahun 1914 di Jailolo bergejolak perang rakyat Jailolo melawan penjajahan Belanda yang dikenal dengan Perang Jailolo atau Rogu Lamo Jailolo. Masjid Gammalamo sebagai markaz para pejuang menyusun srategi dan memperkuat pertahanan melawan penjajahan Belanda. Belanda mengeksploitasi harta kekayaan masyarakat Jailolo dan mewajibkan mereka membayar upeti atau pajak kepada belanda. Belanda menerapkan sistem tanam paksa terhadap perkebunan rakyat. Belanda pun mempekerjakan masyarakat secara rodi tanpa upah bayaran bagi masyarakat. ${ }^{11}$

Masjid ini juga sebagai benteng muslim Jailolo dan Pemimpin Banau untuk menangkal dan menghalangi misi kristenisasi yang dijalankan oleh pemerintah Belanda. Seluruh rakyat Jailolo beserta para imam Masjid Gammalamo berdoa bersama dan menyusun strategi mengusir Kompeni Belanda dari Jailolo. ${ }^{12}$ Belanda ingin meluaskan misi kristenisasi di tanah tersebut dengan mendirikan sekolah zendiq bagi misionaris. Sekolah zendeling (dalam bahasa Belanda

\footnotetext{
10 Wawancara Awwad Lolory Jogogo Kesultanan Jailolo, (22-29 April 2014).

11 Wawancara: Ustaz Saifuddin, Ketua PPP/Ustaz (Jo Kalem) Jailolo (22-29 April 2014).

12 Wawancara: Kakek It, (22-29 April 2014).
} 
pengutusan) yang ditujukan untuk penyebaran agama Kristen melalui kabar keselamatan yang diberikan Allah kepada seluruh dunia. ${ }^{13}$

Masjid Gammalamo sejak awal berdiri sampai sekarang sudah mengalami perubahan nama dua kali dan renovasi sebanyak tiga kali. Awalnya masjid ini sebuah surau atau langgar tanpa nama yang digunakan untuk melaksanakan shalat berjamaah lima waktu. Namun pada tahun 1920 setelah dipindahkan ke lokasi baru masjid ini bernama Masjid Al-Kabir yang berarti masjid besar yang menjalankan adat berlandaskan pada Islam adat matoto agama. Masjid besar sarana untuk mempertahankan akidah Islam dari pengkristenisasian dan pendangkalan akidah yang dilancarkan oleh Kolonial Belanda. Masjid besar tempat menyusun strategi dan benteng perjuangan mengusir Kolonial Belanda dari Jailolo. ${ }^{14}$

Pada tahun 1960 masjid ini direnovasi dengan tidak mengubah desain arsitektur asli bangunan. Letnan Miring sebagai penanggungjawab perbaikan masjid bersama panitia pembangunan masjid Raqib Abdus Samad memperbagus dan memperindah arsitektur bangunan masjid. Setelah selesai perenovasian bangunan masjid, penamaan masjid ini pun diubah lagi dengan nama Masjid Al-Amin masjid saksi sejarah kejayaan Kesultanan Jailolo, ketangguhan pejuang Jailolo melawan penjajah Belanda, kebersamaan rakyat Jailolo dalam menegakkan syiar Islam dan akidah bersendikan adat batoto agama Rasulullah dalam menghadapi pendangkalan akidah dari misi pengkristenisasian. ${ }^{15}$

Pada tahun 1993 sejak kemunculan anak cucu keturunan Sultan Jailolo Abdullah Abdul Rahman Haryanto Syah di Tagalaya Jailolo yang dinobatkan sebagai pewaris tahta Kesultanan Jailolo, maka

\footnotetext{
13 Wawancara: Ustaz Saifuddin, Ketua PPP/Ustaz (Jo Kalem) Jailolo (22-29 April 2014).

14 Wawancara: Rufai Khatib Masjid Gammalamo, (22-29 April 2014).

15 Wawancara Hasyim Imam Masjid Gammalamo, (22-29 April 2014)
}

Masjid Gammalamo menjadi masjid yang diklaim oleh keluarga Sultan menjadi masjid kesultanan. Masjid Al-Amin berubah namanya menjadi Masjid Gammalamo yang pengelolaannya berdasarkan manajemen dan strukturisasi Kesultanan Jailolo. Kehadiran Kesultanan Jailolo mengembalikan nilai historis kejayaan Maloko Kie Raha. Maloko Kie Raha dalam Bahasa Ternate berarti tempatnya empat gunung yang kemudian dialihartikan kekuasaan empat kesultanan, yaitu Ternate, Tidore, Jailolo, dan Bacan. ${ }^{16}$

Keempat Kesultanan tersebut bermufakat dalam Konfederasi Moti tahun 1322 untuk mempererat persatuan dan kesatuan dengan menjaga dan memelihara keamanan serta keutuhan wilayah Moloku Kie Raha. Keempat Kesultanan membagi wilayah kekuasaannya yaitu Pertama, Jailolo: Jiko ma-kolano penguasa teluk; kedua, Tidore: Kie ma-kolano penguasa gunung; ketiga, Ternate Kolano Maluku penguasa Maluku; dan keempat, Bacan Dehe ma-kolano penguasa tanjung. ${ }^{17}$

Selain itu mereka berupaya untuk memperkuat dan memperteguh satu pemahaman budaya yang disebut dengan nama Budaya Kie Raha yang berlandaskan pada filosofi Jou Se Ngofa Ngare. Mereka menyadari dan memahami eksistensi nya adalah satu asal seperti dikatakan oleh Naidah dalam Hikayat Ternate bahwa Maloko Kie Raha ma asal rimoi bato, ma kabasaran se ma istiadat rimoi bato. Empat gunung Maluku sesungguhnya punya satu asal usul punya kemegahan dan kultur yang sama. Untuk itu mereka berfilosofi doka nena marimoi ngone future (bersatu kita teguh bercerai kita runtuh). ${ }^{18}$

16 Wawancara Gamaluddin Gaffar Pemerhati Sejarah dan Budaya Moloku Kie Raha, (22-29 April 2014).

17 Adnan Amal. Kepuluan Rempah-Rempah Perjalanan Sejarah Maluku Utara 1250-1900. (Jakarta: Kepustakaan Populer Gramedia, 2010), h. 20 .

18 Jusuf Abdurrahman, Kesultanan Ternate, Ternate: Lembaga Kebudayaan Daerah Moloku Kie Raha, 1999), h. 78. 


\section{Arsitektur Bangunan Masjid Gammalamo}

Arsitektur adalah hasil proses perancangan dan pembangunan para designer dalam memenuhi kebutuhan fisik sekaligus metafisik, memenuhi unsur raga maupun kejiwaan masyarakat ${ }^{19}$. Setiap konstruksi bangunannya mengandung makna sebagai penanda khazanah budaya masyarakat. Setiap tanda merupakan sesuatu yang menstruktur dan terstruktur ${ }^{20}$ Sebagaimana halnya arsitektur Masjid Gammalamo merepresentasikan budaya masyarakat Jailolo.

\section{Atap Masjid}

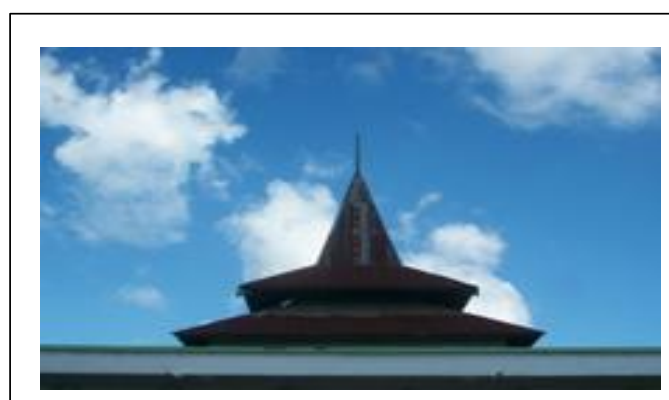

Gambar 1. Atap Masjid (Sumber: Dokumen Novita Siswayanti, 2014)

Atap Masjid Gammalamo berundakundak berbentuk tajug. Atap tajug serupa dengan tipe atap masjid di daerah Jawa seperti Masjid Demak yang beratap tajug puncak atapnya berbentuk piramidal dihiasi dengan mustaka (DEPAG,1999: 67) Pada bagian puncak atap masjid terdapat mustaka berbentuk alif perlambang wujud keimanan kepada Allah. Pada atap masjid terdapat angin-angin yang bertingkat empat perlambang Maloku Kei Raha empat wilayah Kesultanan yang ada di Maluku Utara yaitu Jailolo, Ternate, Tidore, dan Bacan. Selain itu juga melambangkan silsilah turun temurun keturunan Jailolo. ${ }^{21}$

\footnotetext{
${ }^{19}$ Achmad Fanani, Arsitektur Masjid, (Yogyakarta: Bentang, 2009), h. 11.

20 Benny Hoed, Semiotik dan Dinamika Sosial Budaya, (Jakarta: Komunitas Bambu, 2011), h. 3.

${ }^{21}$ Wawancara Ustaz Syuaib Jo Kalem Masjid Jalan Baru, (22-29 April 2014).
}

\section{Ruang Utama Masjid}

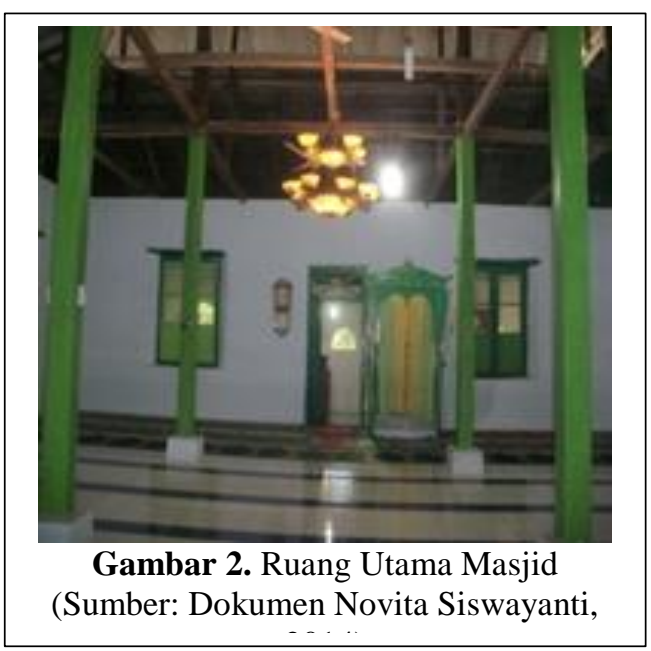

Masjid Gammalamo berkonstruksi bangunan rumah Joglo di Jawa disanggah oleh empat soko guru atau tiang kaba seperti masjid Ternate dan Demak. $^{22}$ Ruang utama masjid berukuran geometris $11 x 11$ meter pada keempat sisinya dengan ketinggian 5 meter. Bangunan masjid disanggah empat tiang taba' bewarna hijau tua masing-masing tingginya 4,5 meter berdiameter $78 \mathrm{~cm}$ dengan dudukan berukuran tinggi $24 \mathrm{~cm}$ dan panjang 40 $\mathrm{cm}$. Empat tiang kaba' berfungsi untuk menguatkan bangunan supaya terhindar dari musibah. Empat tiang kaba'juga merupakan simbol pemersatu dan representasi empat suku yang ada di Jailolo, yaitu Moro, Gamlamo, Wayuli dan Purniti. Walau keempat suku itu memiliki keyakinan dan kepercayaan yang berbeda, yaitu Islam dengan Kristen, namun mereka bersatu padu berpartisipasi dan berkontribusi dalam pembangunan Masjid Gammalamo. ${ }^{23}$

Dinding masjid Gammalamo berdiri kokoh di atas pondasi balok-balok kayu besi asal dari Gufasa (kayu ulin sebutan orang Banjar) dan berbahan dasar batu karang yang sudah dihancurkan, dibakar menjadi kapur yang direkatkan dengan

22 Yulianto Sumalyo, Arsitektur Masjid dan Monumen Sejarah Muslim, (Yogyakarta: Gajah Mada University Press, 2006), h. 512.

${ }^{23}$ Wawancara Awwad Lolory Jogogo Kesultanan Jailolo, (22-29 April 2014). 
campuran pasir dan getah kayu sehingga kekuatan dinding masjid makin tahan lama dan berdiri kokoh dalam jangka waktu bertahun-tahun bahkan ratusan tahun. ${ }^{24}$

Ruang utama Masjid Gammalamo memiliki tiga buah daun pintu dan delapan buah jendela yang masing-masing tiga buah jendela berukuran tinggi $185 \mathrm{~cm}$, lebar $140 \mathrm{~cm}$ dan tepiannya $40 \mathrm{~cm}$. Ketiga pintu itu posisinya berdampingan menghadap ke arah Barat melambangkan tiga sendi dasar kesempurnaan Islam yaitu akidah, ibadah, dan akhlak. Masingmasing pintu berukuran tinggi $2,5 \mathrm{~m}$ dan lebar $1,5 \mathrm{~m}$ dengan tinggi teralis $66 \mathrm{~cm}$ dan lebar $33 \mathrm{~cm}$. Daun pintu masjid berbahan kaca bening transparan dan bagian bawah berbahan kayu perpaduan warna hijau tua dan hijau muda dan ventilasinya berbentuk silang belah ketupat simbol penjelajah Teluk Jailolo.

Pada ruang utama masjid terdapat mihrab sebagai penentu arah kiblat shalat dan sebagai tempat imam memimpin shalat. $^{25}$ Komstruksi mihrab Masjid Gammalamo didesain berbentuk ruangan segiempat ukuran $2.8 \mathrm{~m} \times 1.2 \mathrm{~m}$ menonjol ke depan menghadap ke arah kiblat. Mihrab masjid ditandai gapura tanpa helai daun pintu dengan atap berventilasi bentuk silang dihiasi pahatan kayu bentuk bulan sabit dan bintang bewarna kuning keemasan sebagai simbol tegaknya kejayaan Islam di masa kejayaan Kesultanan Jailolo penjelajah lautan penguasa teluk di Jailolo. $^{26}$ Warna masjid berdominasi kuning keemasan dalam tradisi Melayu berkaitan dengan simbol kesultanan sebagaimana halnya Masjid Al-Mashum Medan. ${ }^{27}$

\footnotetext{
${ }^{24}$ Wawancara: M. Samad, (22-29 April 2014).

25 Aboe Bakar, Sejarah Masjid dan Amal Ibadah di Dalamnya. (Jakarta: NV Viss and Co., 1955), h. 105.

26 Wawancara Gamaluddin Gaffar Pemerhati Sejarah dan Budaya Moloku Kie Raha, (22-29 April 2014).

27 Yulianto Sumalyo, Arsitektur Masjid dan Monumen Sejarah Muslim, (Yogyakarta: Gajah Mada University Press, 2006), h. 486.
}

\section{Mimbar Masjid}

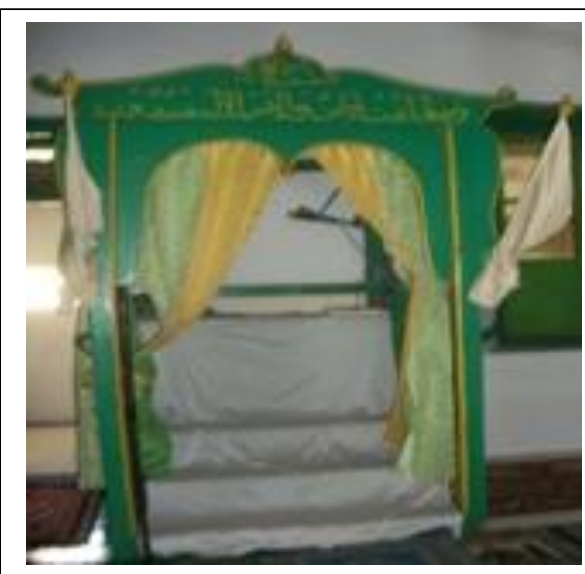

Gambar 3. Mimbar Masjid (Sumber: Dokumen Novita Siswayanti, 2014)

Mimbar masjid Gammalamo berbentuk kubus mirip bilik atau kamar yang diperuntukkan bagi penceramah/khatib Jumat. Mimbar masjid tanpa atap langsung ke langit-langit. Dinding mimbar masjid berkombinasi warna hijau dan kuning sebagai simbol toleransi dan keluhuran budi pekeri masyarakat Jailolo. Dinding mimbar masjid bagian samping kiri dan kanan berjerejak kayu ukir berbentuk spiral berjumlah lima buah. Pada bagian atas jerejak kayu ukir terdapat kaligrafi aksara Arab bertinta kuning keemasan bertuliskan kalimat Laa ilaaha illallahu Muhammadar Rasuulullah. Mimbar masjid terpasang bendera mengisyaratkan masjid kesultanan seperti mimbar Masjid Lawang Kidul Palembang berbendera Ksultanan Palembang Darussalam. ${ }^{28}$ Mimbar masjid bergapura dengan atap berbentuk seperti perahu di ujung kiri kanannya ukiran naga emas kekuningan. Pada bagian atas gapura berbentuk kubah dengan mustaka bewarna emas sebagai perisai bagi Kesultanan Jailolo. Hal ini menyimbolkan Jailolo sebagai kesultanan penjelajah dan penguasa kawasan teluk di Maluku Utara. Pada atap gapura terdapat tulisan kaligrafi aksara Arab bertinta kuning keemasan bergaya tulisan khat riq'ah. Kaligrafi

28 Asti Kleinsteuber, Masjid-Masjid Kuno di Indonesia Warisan Budaya dari Masa ke Masa, (Indonesia: Genta Kreasi Nusantara, 2012), h. 197. 
tersebut ditulis secara bertingkat mulai dari kalimat Allah, Muhammad, dan Surah azZariyaat ayat 56 berbunyi: Wamaa khalaqtul insa wal jinna illa liya 'buduuna. ${ }^{29}$

Mimbar Masjid Gammalamo pada dinding kiri kanannya ditutupi oleh tirai seperti halnya dengan Masjid Sigi Lamo Ternate yang dinding mimbarnya ditutupi tirai. ${ }^{30}$ Tirai ini dimaksudkan agar khatib yang memberikan khutbah/ceramah terjaga dan terpelihara dari segala fitnah yang akan menimpanya. Mimbar masjid berundakundak/bertingkat tiga. Tangga pada mimbar dan tempat duduk khatib ditutupi oleh kain bewarna putih sebagai lambang kepribadian khatib yang bersih jasmani, suci rohani, dan jernih akal pikiran. ${ }^{31}$

\section{Tongkat Khatib}

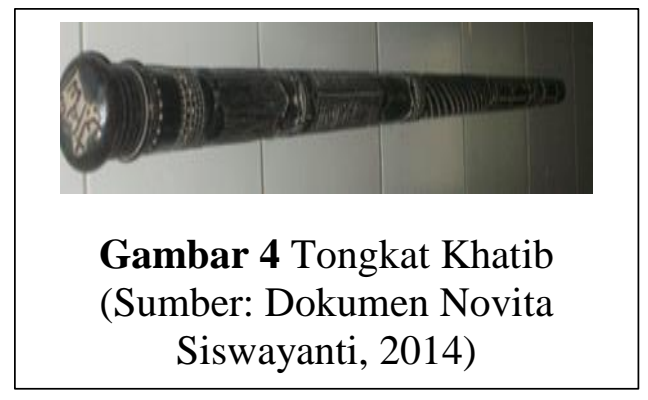

Di Masjid Gammalamo khatib saat berkhutbah bertumpu pada tongkat seperti halnya khutbah Jumat di Masjid Jami Sultan Abdurrahman Pontianak khatib memegang tongkat yang terbuat dari kayu ulin. $^{32}$ Tongkat khatib yang bersandar pada mimbar masjid merupakan hadiah dari seorang tentara yang bertugas di Pulau Buru (Wawancara: Hasyim, 2014). Tongkat berbentuk seperti pena ini berukuran panjang $1 \mathrm{~m}$ bewarna hitam ini penuh dengan beragam ukiran timbul dari ujung hingga pangkalnya. Tongkat ini dinamakan

\footnotetext{
${ }^{29}$ Wawancara Ustaz Syuaib Jo Kalem Masjid Jalan Baru. (22-29 April 2014).

30 Yulianto Sumalyo, Arsitektur Masjid dan Monumen Sejarah Muslim, (Yogyakarta: Gajah Mada University Press, 2006), h. 551.

${ }^{31}$ Wawancara: Hasani, (22-29 April 2014).

32 Departemen Agama, Badan Litbang Agama, Sejarah Masjid-Masjid Kuno di Indonesia, (Jakarta: Badan Litbang Agama Departemen Agama, 1999), h. 92.
}

tongkat alif menandakan satu/tunggal tidak ada sekutu bagiNya. ${ }^{33}$

Pada ujung tongkat alif tergores kaligrafi indah beraksara Arab khat nasakh bertuliskan kalimat Allah dan Muhammad. Selain itu ada empat kaligrafi pada tongkat alif yang bertuliskan potongan ayat-ayat suci Al-Qur'an dan Hadis Rasulullah yaitu: Pertama, iqra bismi rabbika Bacalah dengan menyebut nama Allah; Kedua, ashshalaatu imaaduddin Shalat adalah tiang agama; Ketiga, wawajadaka dhallan fahada dan Dia mendapatimu sebagai seorang yang bingung, lalu Dia memberikan petunjuk dan Keempat, Aqimish shalaata Dirikanlah shalat.

\section{Serambi Masjid}

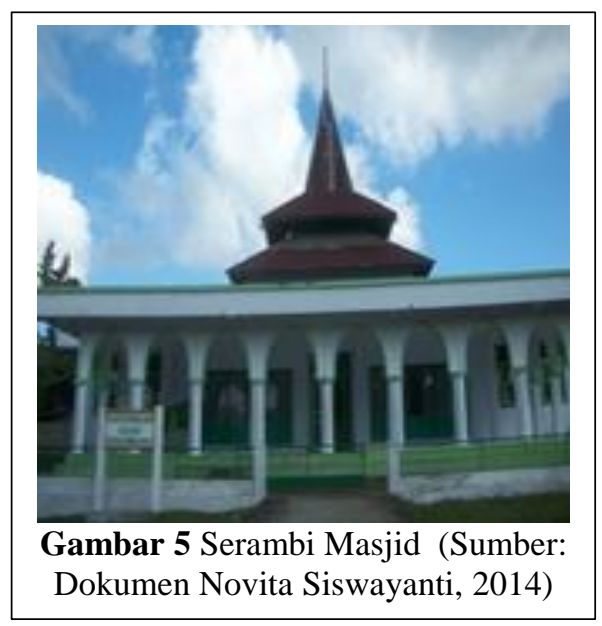

Masjid Gammalamo berkonstruksi bangunan Joglo dikelilingi serambi seperti halnya Masjid Demak yang bagian kiri, kanan, dan depan dikelilingi serambi. ${ }^{34}$ Masjid Gammalamo memiliki dua serambi yaitu serambi yang berada di bagian dalam yang digunakan sebagai tempat shalat di mana lantainya diberi tanda shaf batasan barisan berubin warna biru. Sedangkan serambi masjid bagian depan tanpa dinding tetapi disanggah oleh tiang-tiang berbentuk moris seperti halnya Masjid di

\footnotetext{
${ }^{33}$ Wawancara: Madim, (22-29 April 2014).

34 Departemen Agama, Badan Litbang Agama, Sejarah Masjid-Masjid Kuno di Indonesia, (Jakarta: Badan Litbang Agama Departemen Agama, 1999), h. 67
} 
Andalusia $^{35}$ Tiang moris berbentuk kubah dengan kombinasi warna putih dan hijau muda. Tiang moris berjumlah sembilan buah sebagai representasi sembilan soa sio (desa muslim yang ada di wilayah Jailolo) yaitu:

Gammalamo, Susupu,Payo,Saria,Dodinga, Tauro, Bobaneigo, Sidangoli, Akelamo Kao. Konstruksi latar serambi masjid yang terbuka merepresentasikan keterbukaan dan keramahan masyarakat Jailolo. ${ }^{36}$

\section{Peran Masjid Gammalamo Sebagai Pelestari Warisan Budaya Kesultanan Jailolo}

\section{Lembaga Keagamaan}

Masjid Gammalamo sebagai lembaga keagamaan di bawah legitimasi Kesultanan Jailolo ditandai dengan pembentukan institusi kesultanan yang disebut Bobato Akherat atau Jolebe di samping Bobato Dunia yang mengurus halikhwal keduniaan. Bobato Akhirat bertugas mengurus atau mengatur segala hal ikhwal persoalan ibadah/syariat/sosioekonomi ritual keagamaan masyarakat muslim. Bobato akhirat atau jolebe disebut bobato berjubah putih (semacam pakaian panjang melewati lutut dilengkapi dengan desar (ikat kepala) sementara bobato dunia disebut bobato berjubah hitam. ${ }^{37}$

Bobato Akhirat dipimpin langsung oleh Sultan yang berperan sebagai imam agung. Fungsi Sultan selain sebagai pemimpin pemerintahan dan pemangku tertinggi adat dan tradisi, juga sebagai pemimpin tertinggi agama Islam dengan gelar Amiruddin. Predikat ini bukan sekedar simbol spiritual tetapi membawa konsekuensi pembebanan sejumlah tugas keagamaan kepada sultan baik pelaksanaan hukum Islam maupun tugas sosioekonomi untuk kepentingan rakyat

\footnotetext{
35 Yulianto Sumalyo, Arsitektur Masjid dan Monumen Sejarah Muslim, (Yogyakarta: Gajah Mada University Press, 2006), h. 489.

${ }^{36}$ Wawancara: M. Samad, (22-29 April 2014).

37 Adnan Amal, Maluku Utara Perjalanan Sejarah 1250-1800, (Ternate: UNKHAIR, 2002), h. 129131.
}

dan agama. Sultan sebagai Amiruddin berkewajiban melindungi dan menjaga agama Islam dari berbagai praktek yang mencemarkannya. ${ }^{38}$

Sejak Masjid Gammalamo dilegitimasikan menjadi Masjid Kesultanan Jailolo, masjid dikelola dan difungsikan sesuai dengan manajemen dan strukturisasi kesultanan. Masjid Gammalamo dikelola menurut tradisi dengan membentuk lembaga imamah empat kelompok imam yang dikenal dengan nama bubala raha (empat bagian) yang masing-masing bertugas seminggu sekali sesuai jumlah Jumat dalam satu bulan. Bubala Raha (empat imam) berperan sebagai hakim syara yang bertugas dan bertanggung jawab terhadap dua hal yaitu:

Pertama, Tugas-tugas yang berkaitan dengan ritual keagamaan yang ditujukan untuk menjaga dan memelihara kehidupan spiritual rakyat yaitu shalat fardhu, shalat jumat dan yang bertalian dengan pemeliharaan jenazah, kenduri, maupun hajat lainnya. Selain itu juga mengurusi pelaksanaan shalat Idul Fitri dan Idul Adha, shalat tarawih di bulan Ramadhan. dan Kedua adalah menetapkan awal dan akhir Ramadhan, menjadi amil dalam pengumpulan zakat dan sedekah serta tugas lainnya seperti sunatan, pernikahan dan sebagainya. ${ }^{39}$

Adapun empat imam tersebut terdiri dari: Imam Jiko,Imam Jawa,Imam Soa-Sio dan Imam Sangaji. Seluruh imam dalam bubula raha dikepalai oleh seorang imam yang disebut dengan jo kalem Masingmasing imam dibantu oleh seorang khatib, sehingga jumlah keseluruhan khatib adalah empat orang. Masing-masing khatib membawahi dua orang modim (muazin masjid yang bertugas mempersiapkan fasilitas serta sarana dan prasarana pelaksanaan ibadah), sehingga jumlah keseluruhan modim adalah 8 orang. Pengurus

\footnotetext{
38 Adnan Amal, Maluku Utara Perjalanan Sejarah 1250-1800, (Ternate: UNKHAIR, 2002), h. 29-30.

${ }^{39}$ Wawancara: Hasan, (22-29 April 2014).
} 
lembaga imamah bekerja secara sukarela tanpa pamrih, ikhlas karena Allah. ${ }^{40}$

\section{Tata Cara Pelaksanaan Ibadah}

Masjid Gammalamo dalam pelaksanaan tradisi ritual keagamaan berasaskan pada Adat Moloku Kie Raha Matoto Agama Rasulullah, maksudnya adat seaturan di wilayah Maluku Utara dijiwai oleh agama yang dibawakan Jou Rasulullah yakni agama Islam. Masjid Gammalamo berfungsi sebagai tempat shalat dan beribadah kepada Allah. Masjid kesultanan yang dikhususkan untuk kaum laki-laki melaksanakan segala aktifitas ibadah untuk mendekatkan diri kepada Allah seperti shalat berjama'ah, zikir, maupun tilawah Al-Qur'an. ${ }^{41}$

Sebagai masjid kesultanan Masjid Gammalamo dipimpin oleh imam yang berasal dari keturunan Jailolo bukan dari bangsa atau suku lain. ${ }^{42}$ Seperti masjid lainnya di Kesultanan Moloku Kie Raha imam masjid beserta khatib berpakaian jubbah lengkap dengan tutup kepala (disebut laster sejenis kopiah ala sufi seperti torbus bentuknya tidak lonjong yang dipadu dengan sorban beragam warnanya, sementara modin menggunakan gamis putih dan laster turki (warna merah ikatan putih). ${ }^{43}$

Selain itu tata cara beribadah yang khusus tampak terlihat di Masjid Gammalamo adalah semua jamaah lakilaki mengenakan celana panjang dan tutup kepala saat menunaikan shalat khususnya shalat Jumat. Keharusan memakai peci bagi kaum laki-laki sesuai dengan kebiasaan Rasulullah memakai sorban dan kopiah saat menunaikan shalat. Sebagaimana Hadis yang diriwayatkan oleh Imam Baihaqi

40 Tim peneliti IAIN Ternate, Sejarah Sosial Kesultanan Ternate, (Jakarta: Puslitbang Lektur dan Khazanah Keagamaan, 2010), h. 112.

${ }^{41}$ Wawancara Hasyim Imam Masjid Gammalamo, (22-29 April 2014).

42 Wawancara Hasyim Imam Masjid Gammalamo, (22-29 April 2014).

${ }^{43}$ Wawancara: Hasan, (22-29 April 2014). bahwa "Sesungguhnya Rasulullah SAW memakai serban bersama kopiah". ${ }^{4}$

Sebelum shalat lima waktu didirikan, terlebih dahulu bedug ditabuh sebagai penanda masuknya waktu shalat. Bedug ditabuh sebanyak dua kali; tabuhan pertama jumlahnya disesuaikan dengan waktu dan jumlah rakaat shalat sedangkan tabuhan kedua berjumlah lima ketukan dengan tabuhan terputus-putus. Pada malam Jumat setelah Magrib bedug dipukul bertalu-talu dengan ritme lebih cepat sebagai penanda bahwa besok Hari Jumat. Bedug ini dimaksudkan untuk menyerukan kepada umat muslim khususnya kaum laki-laki untuk menunaikan shalat Jumat berjamaah di masjid. Pada hari jumat bedug dipukul panjang lalu pelan pelan dengan durasi dan jeda ketukan pertama 7 kali pendek kemudian 3 kali panjang selanjutnya azan. ${ }^{45}$

Pada pelaksanaan shalat Jumat masing-masing khatib yang berjumlah empat orang bertugas memberikan khutbah secara bergiliran dan berurutan baik itu minggu pertama, kedua, ketiga, dan keempat. Pada waktu shalat Jumat keempat khatib datang menunaikan shalat jumat berjamaah di Masjid Gammalamo. Mereka menempati tempat yang sudah disediakan yaitu masing-masing khatib berdiri dan shalat di dekat tiang kaba' (empat tiang soko guru). Posisi berdiri keempat khatib sesuai urutannya, tertib pada tempatnya dan tidak boleh berubah atau bertukar. Hal ini dimaksudkan untuk menjaga kesopanan dan saling menghormati antarsesama khatib dan sesama muslim. Pada saat azan, keempat khatib berdiri di tengah-tengah tiang kaba'. Setelah itu salah seorang khatib yang bertugas naik ke atas mimbar untuk menyampaikan khutbah Jumat. ${ }^{46}$

\footnotetext{
44 Wawancara Ibrahim Hi Ahmad, Imam Masjid Sigi Lamo Ternate, (22-29 April 2014).

${ }^{45}$ Wawancara: Hasan Haji, (22-29 April 2014).

46 Wawancara Ustaz Tajuddin Imam Masjid Gammalamo, (22-29 April 2014).
} 


\section{Falsafah Adat Orang Jailolo}

Moloku Kie Raha dalam hal ini Kesultanan Jailolo adalah sebuah kawasan kultural yang merupakan kesatuan majemuk yang akomodatif terhadap perubahan yang dinamis dan pengakuan terhadap heterogenitas kemanusiaan. Masyarakat Jailolo memiliki filosofi Jou Se Ngofangare yang bermakna teologis dan humanistik dalam memaknai eksistensinya sebagai manusia adalah ciptaan Tuhan Yang Mahakuasa. secara harfiah filosofi Jou Se Ngofangare mengandung makna Tuhan dan Aku. Tuhan sebagai awal dari segala kejadian. Manusia adalah ciptaan Tuhan yang tidak lepas dari dimensi-dimensi teologis. Secara teologis Jou Se Ngofangare merupakan representasi kebudayaan melalui pendekatan lokal untuk memahami makna proses syahadat yang pada intinya adalah penghormatan Tuhan kepada hambanya yang menempati manusia pada posisi yang paling tinggi dan terhormat.Dalam hal ini basis peradaban Moloku Kie Raha memposisikan semua manusia sama di hadapan Tuhan. ${ }^{47}$

Filosofi Jou Se Ngofa Ngare merupakan puncak kesadaran ilahiah yang transendetal mempersonifikasikan KuasaNya melalui pendelegasian sifatsifatnya kepada manusia. Manusia diciptakan berdasarkan sifat Rahman dan Rahim Allah Sang Maha Pencipta. Manusia memiliki dimensi yang sakral karena adanya pendelegasian Allah ke dalam dirinya melalui sifat Rahman dan RahimNya. Sifat sifat ilahiah tertulis pada diri manusia dengan perangkat akal budi yang melebur menjadi tri potensi cipta, karsa dan rasa maka terbentuklah suatu peradaban manusia yang merupakan pedoman hidup manusia Maloku Kie Raha yang diterapkan melalui naluri keagamaan

47 Mudaffar Sjah, Moloku Kie Raha dalam Perspektif Budaya dan Sejarah Masuknya Islam. (Ternate: t.p., 2005), h. 44. serta pelaksanaanya melalui perangkat adat se-atorang. ${ }^{48}$

Selain itu dalam tata kehidupan humanistik dengan aturan lisan yang mengikat komunitas orang Jailolo dalam konteks "Masyarakat Adat" bersumber dari Enam Sila Dasar Falsafah Adat yang berlaku dan merupakan warisan nenek moyang. Enam Sila Dasar Falsafah Adat Jailolo ini merupakan implementasi dari akar budaya asli orang Jailolo itu sendiri, yaitu; "Adat ma toto agama, Agama ma toto toma Jou Rasulullah, Jou Rasulullah manyeku Diki Amoi nga hidayah se kodrati". (Adat bersumber dari agama, agama bersumber dari ajaran Rasullulah, dia atas Rasulullah hanya hidayah dan kehendak-Nya atas segalanya".

Enam Sila Dasar Falsafah Adat orang Jailolo adalah merupakan warisan dari para leluhur yang dalam bahasa daerah Jailolo disebut "Kie se Gam Magogugu Matiti Rara", terdiri dari ${ }^{49}$ :

a. Adat Se Atorang; Hukum dasar yang harus dipatuhi dan disusun menurut kebiasaan yang dapat diterima oleh semua lapisan masyarakat. artinya adat yang bersendikan aturan.

b. Istiadat Se Kabasarang; Lembaga adat dengan kekuasaannya menurut ketentuan adat yang berlaku dijunjung tinggi sebagaimana menjaga martabat orang Jailolo.

c. Galib Se Likudi; Kebiasan lama yang menjadi pegangan suku bangsa diatur menurut sendi ketentuan yang dilazimkan dalam masyarakat dan disesuaikan dengan jaman tanpa ada pertentangan. Atau sebuah kesepakatan sebagai peninggalan para leluhur yang harus dihormati dan dijunjung tinggi dijaga dan ditaati keasliannya serta kemurniannya secara turun temurun

d. Ngale Se Cara/Duku; Bentuk budaya masing-masing suku bangsa dapat

48 Mudaffar Sjah, Moloku Kie Raha dalam Perspektif Budaya dan Sejarah Masuknya Islam. (Ternate: t.p., 2005), h. 60-61.

49 Busranto Abdul Latief, Pemerhati Sejarah dan Budaya Moloku Kie Raha, (22-29 April 2014). 
digunakan secara bersama-sama sesuai dengan keinginan untuk keutuhan dalam perbedaan. Dalam hal ini misalnya pelaksanaan upacara kelahiran, pernikahan, kematian dan lainnya mempunyai tata cara sendiri-sendiri yang merupakan suatu kebiasaan masyarakat asalkan tidak bertentangan dengan hukum syara.

e. Sere Se Duniru; Tata kehidupan seni dan budaya dan kebiasaan yang timbul dalam pergaulan masyarakat diterima secara bersama-sama. Misalnya suatu rangkaian pesta adat untuk menghibur diri di kala kesepian atau selesai acara perkawinan yang dianggap perlu dan dalam acara tersebut juga diartikan sebagai ajang untuk saling berbalas pantun atau rangkaian kata bermakna sarana pengujian ilmu pengetahuan.

f. Cing Se Cingare; Ketentuan pengaturan tentang perempuan dan lelakinya. artinya setiap individu maupun pasangan pria dan wanita merupakan kesatuan yang utuh dengan hak dan kewajiban masing-masing perlu dibina dan dijaga kelestariannya karena orang Ternate memaknai filosofi laki-laki dan perempuan dengan Goheba ma dopolo romdidi asal muasal lahirnya marga di Maluku Utara.

\section{Adat Istiadat Ritual Keagamaan a. Tradisi Maulid Nabi}

Kebiasaan masyarakat Jailolo dalam memperingati acara Maulid Nabi (hari kelahiran Rasulullah saw.) direfleksikan dengan membaca barzanji dan sarafal anam. Selepas Maghrib, para Bobato Akhirat atau Para Kadi pengurus masjid Gammalamo sudah menyiapkan tempat berlangsungnya pembacaan Sarafal Anam. Sarafal Anam berisi puji-pujian dan kisah para rosul utusan Allah ke muka bumi, termasuk kelahiran Rasulullah sebagai Khatamul Anbiya. ${ }^{50}$

\section{b. Tradisi Kololi Kie (Keliling Mengelilingi Gunung)}

${ }^{50}$ Wawancara: Hasan, (22-29 April 2014).
Tradisi Kololi Kie mengelilingi gunung menjelang Bulan Ramadhan dibarengi dengan niat tertentu. Masyarakat Jailolo berjalan kaki menyusuri kampungkampung di sepanjang pesisir Teluk Jailolo atau Pulau Moti. Masing-masing pengeliling membawa sebuah dirigen (tempat air tawar), ceret, atau botol menyinggahi setiap masjid dan mengambil sedikit air dari masjid untuk dibawa pulang. Konon ceritanya air bawaan tersebut dipakai untuk air wudhu pertama dan batal puasa pertama di Bulan Ramadhan dan di akhir Ramadhan mereka mengadakan perjalanan kololi kie lagi dengan bawaan iru untuk wudhu dan sembahyang sunah Idul Fitri. ${ }^{51}$

\section{c. Tradisi Khatam Al-Quran}

Tradisi Khatam Al-Quran dilakukan dalam dua versi yaitu: pertama, tasyakuran bagi mereka yang sudah selesai belajar mengaji dan menamatkan bacaan AlQuran 30 juz dan yang kedua, khatam AlQuran selesai para jamaah tadarusan AlQuran di masjid pada Bulan Ramadhan. Pada acara khatam Al-Quran, kaum lakilaki memakai jubbah dan destar, sedangan bagi perempuan mengenakan kerudung. Prosesi khatam Al-Quran dimulai pembacaan Surah Adh-Dhuha hingga Surah Al-Ikhlas, dan diakhiri dengan doa secara bersama-sama yang dipimpin oleh seorang imam. Setelah prosesi khatam Al-Quran selesai, menikmati suguhan makanan adat. $^{52}$

\section{e. Tradisi Ella-Ella}

Tradisi penyambutan Malam Lailatul Qadar malam penuh kemuliaan dengan menyalakan lampu obor dan lilin. Malam Ella-Ella ini berlangsung empat hari menjelang malam terakhir di Bulan Ramadhan tepatnya mulai malam ke-27 di Bulan Ramdhan. Pada malam itu mulai Maghrib sampai pagi lampu terbuat dari damar, kelapa kering hingga obor dan lilin dinyalakan dan diletakkan di depan rumah masing-masing. Mereka menyalakan lampu

\footnotetext{
${ }^{51}$ Wawancara: Kakek It, (22-29 April 2014).

52 Wawancara Awwad Lolory Jogogo Kesultanan Jailolo, (22-29 April 2014).
} 
sambil membaca Surah Al-Qadr, selain itu para anak-anak dan remaja sambil menyalakan obor juga berteriak-teriak elaela pake jam-jam to suba jou (artinya wallahu a'lam). Di lingkungan kesultanan yang dihubungkan dengan Masjid Gammalamo pada malam itu Sultan yang hendak melaksanakan tarawih ditandu secara bergantian oleh para bala kusu sekano-kano atau rakyatnya menuju masjid dengan membawa obor atau lilin sebagai penerang jalan yang disertai dengan tabu gong. ${ }^{53}$

\section{Penutup}

Masjid Gammalamo masjid tertua di Jailolo Halmahera Barat yang berlokasi di pesisir pantai Pelabuhan Dufa-Dufa tepatnya di Desa Gamlamo merupakan bangunan ibadah bersejarah yang menyingkapkan sejarah dan budaya Islam di Jailolo. Jailolo salah satu bagian dari empat kesultanan di Moloku Kie Raha yang memiliki peranan penting dalam pelestarian budaya Moloku Kie Raha di Jailolo dengan perangkat strukturisasi kelembagaan kesultanan. Masjid Gammalamo mewarisi dan merepresentasikan filosofi adat seatorang Moloku Kie Raha "Adat ma toto agama, Agama ma toto toma Jou Rasulullah, Jou Rasulullah manyeku Diki Amoi nga hidayah se kodrati". (Adat bersumber dari agama, agama bersumber dari ajaran Rasullulah, dia atas Rasulullah hanya hidayah dan kehendak-Nya atas segalanya".

Selain itu arsitektur bangunan Masjid Gammalamo yang merupakan bangunan tertua dan pertama di Tuanane Jailolo merepresentasikan simbolisasi persatuan dan kerukunan antarumat beragama di Jailolo. Walaupun mereka berbeda dalam suku dan agama, tetapi Rakyat Jailolo menjaga hubungan baik antarsuku penuh persaudaraan dan kekeluargaan sebagaimana filosofis moi na

53 Wawancara Muhammad Rikzal Amin Mahasiswa IAIN Ternate asal Jailolo. (22-29 April 2014). ngone bato maku gosa jira ifa, dofu sema dofu marimoi bato. Kita sebagai pemilik wilayah Jailolo, peliharalah hubungan baik sesama kita, walau berasal dari kerajaan yang berbeda tetapi kita adalah satu. Masjid Gammalamo sejak didirikan memiliki peranan yang penting dakwah dan penyiaran Islam di Jailolo. Dengan heterogenesis komunitas Halmahera tetapi kerukunan antar umat beragama tetap terjalin satu sama lain saling hormat menghormati.

\section{Daftar Pustaka}

Abdurrahman, Jusuf. 1999. Kesultanan Ternate, Ternate: Lembaga Kebudayaan Daerah Moloku Kie Raha

Ambari, Hasan Muarif. 1998. Menemukan Peranan Jejak Arkeologi dan Historis Islam di Indonesia: Jakarta: Logos Wacana Ilmu.

Amal, Adnan. 2002. Maluku Utara Perjalanan Sejarah 1250-1800. Ternate: UNKHAIR.

Amal, Adnan. 2010. Kepuluan RempahRempah Perjalanan Sejarah Maluku Utara 1250-1900. Jakarta: Kepustakaan Populer Gramedia

Aboe Bakar.1955. Sejarah Masjid dan Amal Ibadah di Dalamnya. Jakarta, NV Viss and Co.

Akbar, Ali. 2010. Arkeologi Masa Kini, Bandung: ALQAPRINT

Departemen Agama, Badan Litbang Agama, 1999, Sejarah Masjid-Masjid Kuno di Indonesia, Jakarta: Badan Litbang Agama Departemen Agama

Djafaar, Irza Arnyta. 2007. Jejak Portugis di Maluku Utara, Maluku Utara: Ombak

Fanani, Achmad, 2009, Arsitektur Masjid, Yogyakarta: Bentang 
Hasan, Abdul Hamid, 1999, Aroma Sejarah dan Budaya Ternate, Ternate, t.p.

Hoed,Benny,2011,Semiotik dan Dinamika Sosial Budaya,Jakarta:Komunitas Bambu.

Kleinsteuber, Asti, 2012, Masjid-Masjid Kuno di Indonesia Warisan Budaya dari Masa ke Masa, Indonesia: Genta Kreasi Nusantara

Sjah, Mudaffar. 2005. Moloku Kie Raha dalam Perspektif Budaya dan Sejarah Masuknya Islam. Ternate: t.p. (tanpa penerbit)

Rochym, Abdul. 1983. Masjid dalam Karya Arsitektur Nasional Indonesia. Bandung: Angkasa

Sumalyo, Yulianto, 2006, Arsitektur Masjid dan Monumen Sejarah Muslim, Yogya: Gajah Mada University Press

Tim peneliti IAIN Ternate. 2010. Sejarah Sosial Kesultanan Ternate. Jakarta: Puslitbang Lektur dan Khazanah Keagamaan

Keraton Jailolo Bakal Ditempati. (http://poskomalut.com/2013/12/06/k eraton-jailolo-bakal-ditempati. diakses Mei 2014).

Memahami Falsafah Adat Orang Ternate (http://www.pewarta-indonesia.com/ inspirasi/sosial-a-budaya/1054memahami-falsafah-adat-orangternate. diakses 5 Mei 2014)

Patriotisme Seorang Banau Dalam Perang Jailolo Tahun 1914 Pahlawan Yang Terlupakan (http://ternate.wordpress.com/2007/ 04/07/patriotisme-seorang-banaudalam-perang-jailolo-tahun-1914- pahlawan-yang-terlupakan, diakses 9 Mei 2014)

\section{INFORMAN}

Wawancara dengan informan dilaksanakan tanggal 22-29 April 2014

1. Busranto Abdul Latief, Pemerhati Sejarah dan Budaya Moloku Kie Raha

2. Gamaluddin Gaffar Pemerhati Sejarah dan Budaya Moloku Kie Raha

3. Awwad Lolory Jogogo Kesultanan Jailolo

4. Muhammad Rikzal Amin Mahasiswa IAIN Ternate asal Jailolo

5. Ahmad Haji Imam Masjid Lako Akelamo

6. Ustaz Tajuddin Imam Masjid Gammalamo

7. Hasyim Imam Masjid Gammalamo

8. Madim Jo Kalem/ Ustaz pengajian di Jailolo/ Mantri Kesehatan

9. Ustaz Saifuddin Ketua PPP/Ustaz (Jo Kalem) Jailolo

10. Ustaz Syuaib Jo Kalem Masjid Jalan Baru

11. Rufai Khatib Masjid Gammalamo

12. Ibrahim Hi Ahmad, Imam Masjid Sigi Lamo Ternate 